\title{
Sejarah Perjuangan Mempertahankan Kemerdekaan Indonesia di Lubuklinggau Tahun 1947-1949
}

\author{
Agus Susilo, Sarkowi \\ agussusilo4590@gmail.com, sarkowisulaiman@gmail.com \\ Prodi Pendidikan Sejarah STKIP PGRI Lubuklinggau Sumatera Selatan
}

\begin{abstract}
The purpose of this study was to find out about the history of the struggle for Indonesian independence in Lubuklinggau in 1947-1949. This research method is a historical research method. This research method is a historical research method. In this historical research method, the researcher uses several steps such as Heuristics, Source Verification (Internal and External Criticism), Interpretation, and Historiogfari History. The research sources were obtained through library research at the Garuda Sriwijaya Subkoss Museum in the form of historical archives and at the STKIP PGRI Lubuklinggau Library. The results of this study, namely a) Indonesia's Struggle in Defending Independence in 1947-1949, namely after trying to become independent after Japan surrendered to the Allies, the Indonesian people tried to become an independent country on August 17, 1945. desire to return to power in Indonesia. So there was a war of independence between the years 1947-1949. The role of the Subkoss in Lubuklinggau in 1947-1949 As the Indonesian Defense Base in South Sumatra, namely after the sabotage of the Dutch troops against the independence fighters in Palembang, a 5 day 5 night war broke out. As a result of the war, Indonesian troops in Palembang tried to build strength in several areas, including in Lubuklinggau. In Lubuklinggau in 1947-1949 it became the center of the Garuda Sriwijaya Subkoss, South Sumatra in repelling the Dutch attack who was trying to catch up with TNI troops and the Laskar. The Indonesian struggle was finally successful with the recognition of Indonesia's independence in 1949 de facto and de jure by the Netherlands and the world. The conclusion is that the struggle for independence in Lubuklinggau was a result of the Dutch military aggression II which continued to attack South Sumatra. Through the Garuda Sriwijaya Sub-Commandment, Lubuklinggau City became a defense base in defending itself from the Dutch attacks that would continue to dominate South Sumatra.
\end{abstract}

Keywords: History, Struggle, Independence, Lubuklinggau 1947-1949

\section{Abstrak}

Tujuan dari penelitian ini adalah untuk mengetahui tentang Sejarah Perjuangan Mempertahankan Kemerdekaan Indonesia di Lubuklinggau Tahun 1947-1949. Metode penelitian ini adalah metode penelitian Sejarah. Dalam metode penelitian Sejarah ini peneliti menggunakan beberapa langkah seperti Heuristik, Verifikasi Sumber (Kritik Intern dan Ekstern), Interpretasi, dan Historiografi Sejarah. Sumber-sumber penelitian yang didapatkan melalui studi pustaka di Museum Subkoss Garuda Sriwijaya berupa arsip-arsip Sejarah dan di Perpustakaan STKIP PGRI Lubuklinggau. Hasil dari penelitian ini, yaitu Perjuangan Indonesia Dalam Mempertahankan Kemerdekaan Tahun 1947-1949, yaitu setelah berusaha memerdekakan diri pasca Jepang menyerah 
Agus Susilo, Sarkowi

Sejarah Perjuangan Mempertahankan Kemerdekaan Indonesia

di Lubuklinggau Tahun 1947-1949

kepada Sekutu, bangsa Indonesia berusaha untuk menjadi negara merdeka pada tanggal 17 Agustus 1945. Namun demikian, langkah tersebut dicampuri dengan kedatangan Belanda yang berkeinginan berkuasa kembali di Indonesia. Sehingga terjadi perang kemerdekaan antara tahun 1947-1949. Peran Subkoss di Lubuklinggau Tahun 1947-1949 Sebagai Basis Pertahanan Indonesia di Sumatera Selatan, yaitu setelah sabotase pasukan Belanda terhadap pejuang kemerdekaan di Palembang maka pecahlah perang 5 hari 5 malam. Oleh akibat peperangan tersebut pasukan Indonesia di Palembang berusaha menyusun kekuatan di beberapa daerah termasuk di Lubuklinggau. Di Lubuklinggau tahun 1947-1949 dijadikan pusat Subkoss Garuda Sriwijaya Sumatera Selatan dalam menghalau serangan Belanda yang berusaha mengejar pasukan TNI dan laskar. Perjuangan Indonesia akhirnya berhasil dengan diakuinya kemerdekaan Indonesia tahun 1949 secara de facto dan de jure oleh Belanda dan dunia. Kesimpulannya adalah perjuangan mempertahankan kemerdekaan di Lubuklinggau adalah langkah akibat agresi militer Belanda II yang terus menggempur Sumatera Selatan. Melalui Sub Komandemen Garuda Sriwijaya, Kota Lubuklinggau menjadi basis pertahanan dalam mempertahankan diri dari serangan Belanda yang akan terus menguasai Sumatera Selatan.

Kata Kunci: Sejarah, Perjuangan, Kemerdekaan, Lubuklinggau 1947-1949

This work is licensed under the Creative Commons Attribution-ShareAlike 4.0 International License

\section{Pendahuluan}

Perjuangan mempertahankan kemerdekaan Indonesia merupakan perjuangan yang berat dan penuh pengorbanan dari segenap bangsa Indonesia. Proklamasi kemerdekaan ini diumumkan pasca Jepang menyerah tanpa syarat kepada Sekutu setelah dijatuhkannya bom atom di Hiroshima dan Nagasaki oleh Amerika Serikat, angin segar inilah yang dimanfaat oleh Golongan Muda untuk meyakinkan Golongan Tua untuk segera memproklamirkan kemerdekaan Indonesia hingga terlaksana pada tanggal 17 Agustus 1945. Setelah menyatakan diri sebagai negara yang merdeka, bangsa Indonesia berhadapan dengan sisa tentara Jepang yang masih bercokol di Indonesia sekaligus pasukan Sekutu dalam hal ini Inggris yang mendapat tugas untuk mengawasi para tahanan Sekutu dan melucuti senjata Jepang di Indonesia (Kansil, 1984).

Proklamasi kemerdekaan yang telah dikumandangkan bukanlah suatu hadiah cuma-cuman tanpa pengorbanan, melainkan suatu babak perjuangan baru bangsa untuk benar-benar lepas dari belenggu penjajahan bangsa lain dengan segenap fikiran, tenaga bahkan nyawa. Kedatangan Sekutu ke 
Indonesia memboncengi NICA (Netherlands Indies Civil Administration) yang tidak lain adalah pasukan Belanda yang pernah menjajah bangsa Indonesia sebelum diduduki oleh pasukan Jepang sejak tahun 1596. Kerajaan Belanda yang telah menjajah dan mendapat keuntungan besar dari hasil ekploitasi terhadap kekayaan bumi Indonesia tentunya tidak menghendaki bangsa Indonesia memperoleh kemerdekaan, namun bagi bangsa Indonesia melepaskan diri dari belenggu penjajahan merupakan hak kodrati setiap manusia (M. Loeb, 2013).

Militansi dan konsistensi bangsa Indonesia dalam menghadapi bahaya setelah dikumandangkan sebagai negara yang merdeka. Bangsa Barat berusaha melakukan berbagai cara untuk menguasainya kembali Indonesia yang dijawab oleh bangsa Indonesia dengan berbagai gejolak dan perlawanan yang terjadi di dalam negeri. Bangsa penjajah berusaha mencari cara untuk dapat masuk kedalam kehidupan rakyat Indonesia dengan berbagai serangan fisik, diplomasi, dan membentuk negara boneka. Tentunya laskar rakyat ikut berjuang bersama TNI melawan penjajah asing yang jelas-jelas akan kembali mengatur dan menjajah bangsa Indonesia. Rakyat adalah kekuatan Tentara Nasional Indonesia saat ini dan di masa lalu, rakyat menjadi ujung tombak perjuangan melalui para laskar yang berjuang untuk mempertahankan kemerdekaan Indonesia (Zuhdi, 2014).

Berita kemerdekaan Indonesia kemudian meluas ke seantero pelosok Nusantara, termasuk di seluruh wilayah Sumatera Selatan. Di Palembang, informasi kemerdekaan ditangkap dengan cepat oleh kelompok A.K. Gani dari berita yang diterima dari Mailan dan Nungcik AR yang bekerja di "Palembang Shimbun" pada tanggal 18 Agustus 1945. Pada tanggal 22 Agustus 1945 tokohtokoh penting di Palembang mengadakan pertemuan dengan pihak Jepang, namun pihak Jepang ini tidak menyinggung masalah proklamasi kemerdekaan Indonesia. Berita proklamasi secara formal diterima dari anggota PPKI wakil Sumatera yaitu Mr. Teuku Moh. Hasan, Mr. A. Abbas dan Dr. Moh. Amir pada 24 Agustus 1945. Saat itu juga disampaikan bahwa kemerdekaan Indonesia tidak ada kaitannya dengan Jepang (Syam, 2010).

Kehadiran kembali Belanda di Indonesia menimbulkan konflik antara Indonesia dan Belanda di berbagai daerah setelah rakyat Indonesia mengetahui bahwa Sekutu membawa pasukan Belanda dalam upaya menegakkan kekuasaannya di Indonesia, sehingga menyebabkan peperangan pertempuran kedua belah pihak (Cribb, Robert, 2012). Peristiwa yang menjadi penyebab pertikaian Indonesia dan Belanda ini semakin tajam sejak tahun 1947 saat Belanda melakukan Agresi Militer Belanda I. Pada saat itu Belanda berusaha untuk menguasai obyek-obyek vital wilayah kekuasaan Indonesia dan 
Agus Susilo, Sarkowi

Sejarah Perjuangan Mempertahankan Kemerdekaan Indonesia

di Lubuklinggau Tahun 1947-1949

mendesak Tentara Nasional Indonesia (TNI) untuk menyerah. Pertikaian tersebut dapat diredam dengan diadakan perjanjian Linggarjati pada tanggal 17 Januari 1948. Dalam perjanjian Linggarjati tersebut wilayah Indonesia semakin sempit, dan pasukan TNI harus mengosongkan kota-kota yang telah masuk dalam kekuasaan Belanda lewat perjanjian Linggarjati tersebut (Setiawan, 2018).

Kedatangan tentara Sekutu yang memboncengi Belanda di berbagai daerah disambut oleh rakyat Indonesia yang terdiri laskar dan pejuang dengan berbagai perlawanan dan pertempuran sengit demi mempertahankan kemerdekaan Indonesia yang akan diambil alih oleh penjajah kolonial Belanda dan sekutu (Limah Hutri, 2018). Pada umumnya bangsa Indonesia telah mempersiapkan diri dengan membentuk Angkatan Muda Indonesia yang didirikan pada tanggal 1 September 1945. Kedatangan Sekutu bukan hanya bertugas melucuti tentara Jepang, namun secara politis juga memposisikan Belanda untuk kembali menguasai Indonesia, hal ini dibuktikan dengan pasukan infanteri dalam jumlah besar yang didatangkan dari India di bawah pimpinan Jenderal Mallaby. Hal ini tentunya menimbulkan kemarahan rakyat Indonesia atas berbagai aksi yang dilakukan oleh Sekutu di beberapa daerah di Indonesia, termasuk di Sumatera Selatan (Ricklefs, 2007).

Untuk wilayah Sumatera Selatan sendiri, Belanda melakukan perundingan dengan pihak Indonesia tepatnya di Lahat. Pada saat perundingan tersebut, pihak Indonesia diwakili oleh Kolonel Maluddin Simbolon selaku Panglima Divisi VIII Garuda dan di pihak Belanda diwakili oleh Kolonel Mollinger untuk melakukan gencatan senjata. Melihat bangsa Indonesia menaati perjanjian Linggarjati yang telah disepakati, pada tanggal 19 Desember 1948 Belanda melakukan Agresi Militer Belanda II dalam langkah terakhir untuk menghancurkan kekuatan TNI yang menjadi basis pertahanan bangsa Indonesia. Agresi Militer Belanda II bukan hanya dilakukan di wilayah Jawa, namun juga di wilayah Sumatera Selatan dengan pertimbangan aspek sosial, ekonomi, dan politik. Sumatera Selatan dinilai Belanda akan menjadi sumber kekuatan dalam segi ekonomi bagi perkembangan kekuasaan Belanda di Indonesia (Rawas, 2002).

Langkah awal yang dilakukan Belanda di Sumatera Selatan adalah menghancurkan kekuatan militer dan menduduki Palembang sebagai pusat politik dan ekonomi, sehingga meletus perang lima hari lima malam dan jatuhnya Palembang ke pihak Belanda, namun pemerintahan sipil berhasil diselamatkan dengan memposisikan Lubuklinggau dan selanjutnya Curup sebagai pusat pemerintahan. Serangan pasukan Belanda dalam melumpuhkan para pejuang kemerdekaan di Sumatera Selatan menyebabkan banyak pejuang 
yang mundur dari pusat Kota Palembang seperti dijelaskan diatas. Untuk menggagalkan keinginan Belanda para pejuang menyusun kekuatan dari berbagai wilayah di Sumatera Selatan. Pengejaran terhadap pejuang kemerdekaan Indonesia di Sumatera Selatan sampai ke berbagai daerah dihambat oleh pasukan TNI dan laskar rakyat dengan strategi perang gerilya. Melihat pergerakan Belanda dengan Agresi Militer Belanda II yang berusaha untuk menguasai Indonesia seperti di masa-masa sebelumnya, pemerintahan militer di Muara Beliti pada tanggal 21 Desember 1948 dipindahkan ke Lubuklinggau. Pemindahan pemerintahan militer ke Lubuklinggau ini didasarkan pada keinginan dalam menjalin konsolidasi dengan Markas Divisi VIII Garuda dikenal dengan sebutan Subkoss (Sub Komando Sumatera Selatan) yang terlebih dahulu berada di Lubuklinggau dan sebagai persiapan gerilya untuk melindungi pemerintahan sipil Karesidenan Palembang di Curup setelah dipindahkan dari Lubuklinggau (Yusuf, 2020).

Penelitian tentang tentang tentang Sejarah perjuangan mempertahankan kemerdekaan Indonesia di Lubuklinggau tahun 1947-1949. Penelitian relevan dilakukan oleh (Fauziah Amatullah, 2020) dengan judul "Peranan Letnan satu Nawawi Manaf di Bengkulu pada masa Revolusi Fisik (1945-1949)" membahas kiprah Letnan Nawawi Manaf di Bengkulu sebagai bagian dari Provinsi Sumatera Selatan pada masa revolusi fisik. Penelitian selanjutnya adalah penelitian (Yusuf Syafruddin, 2020) berjudul "Perjuangan Rakyat Musi Rawas Pada Masa Revolusi Fisik (1947 -1949)" yang mengkaji kiprah rakyat Musi Rawas dalam perang melawan Belanda pada masa Revolusi Fisik di Musi Rawas, Sumatera Selatan.

Penelitian sejarah lokal tentang Sejarah perjuangan mempertahankan kemerdekaan Indonesia di Lubuklinggau tahun 1947-1949 dilakukan sebagai usaha dalam melestarikan dan mengangkat kembali melalui penulisan sejarah lokal perjuangan kemerdekaan Indonesia di Kota Lubuklinggau. Hal ini penting, karena sejarah lokal perjuangan masyarakat Kota Lubuklinggau di masa lalu dalam mempertahankan kemerdekaan Indonesia dari serangan pasukan Belanda sangat besar sekali. Dalam hal ini, adanya sejarah lokal masa perjuangan akan menambah wawasan generasi muda dalam mengembangkan kembali sejarah-sejarah lokal melalui tulisan ilmiah. Penulis tertarik untuk melakukan penelitian ini secara mendalam Sejarah perjuangan mempertahankan kemerdekaan Indonesia di Lubuklinggau tahun 1947-1949. Ada dua fokus permasalahan yang dikaji dalam penelitian ini adalah sejarah perjuangan Indonesia dalam mempertahankan kemerdekaan tahun 1947-1949 dan peran Subkoss di Lubuklinggau tahun 1947-1949 sebagai basis pertahanan Indonesia di Sumatera Selatan 
Agus Susilo, Sarkowi

Sejarah Perjuangan Mempertahankan Kemerdekaan Indonesia

di Lubuklinggau Tahun 1947-1949

\section{Metode Penelitian}

Jenis penelitian yang berjudul "sejarah perjuangan Indonesia dalam mempertahankan kemerdekaan tahun 1947-1949 dan peran Subkoss di Lubuklinggau tahun 1947-1949" merupakan penelitian sejarah. Dalam penelitian sejarah ini, peneliti membahas tentang sejarah perjuangan Subkoss di Lubuklinggau. Untuk teknik penulisan penelitian sejarah ini, peneliti menggunakan metode penelitian sejarah dengan dukungan sumber literatur dari buku Sejarah yang didapatkan di Perpustakaan Daerah dan Kampus STKIP PGRI Lubuklinggau, jurnal Sejarah di akun google scholar, arsip dari rekaman tokoh perjuangan dalam mempertahankan kemerdekaan di Kota Lubuklinggau yang didapatkan di Museum Subkoss Garuda Sriwijaya dan wawancara kepada para tokoh veteran yang masih hidup, tokoh sejarawan Bapak Suwandi Syam, dan pihak Museum Subkoss Garuda Sriwijaya bapak Berlian Susetyo. Sumber-sumber referensi yang terkait dilakukan pengkajian dan menganalisis data dari fakta-fakta yang terverifikasi (interpretasi), kemudian menyajikan hasil data-data yang telah diinterpretasi ke dalam tulisan sejarah (historiografi). Penelitian sejarah sendiri merupakan penelitian yang mengkaji hasil-hasil data yang mengingat perjalanan bangsa di masa lalu (Gottschalk, 2010).

Penelitian ini merupakan penelitian sejarah yang mana kajian penelitiannya adalah penelitian sejarah lokal (Daliman, 2012). Langkah dalam penelitian ini diawali dengan pengumpulan sumber-sumber sejarah (Heuristik). Selanjutnya, sumber sejarah yang didapatkan ini dilakukan kritik sumber yang terdiri dari kritik ekstern dan kritik intern (Kartodirdjo, 2014). Kritik ekstern dilakukan dengan melihat sumber arsip berupa tulisan dan kaset dari sejarah perjuangan subkoss Garuda Sriwijaya tahun 1947-1949. Kritik ekstern ini dilakukan untuk mengetahui keaslian dari peninggalan yang tersimpan di Museum Subkoss Garuda Sriwijaya Lubuklinggau. Kritik intern ini dilakukan dengan melakukan wawancara kepada tokoh perjuangan yang ada di Kota Lubuklinggau, tokoh adat, dan Sejarawan yang mengetahui perjuangan masyarakat Kota Lubuklinggau dalam melawan penjajah belanda di masa lalu (Karima \& Firza, 2018).

Hasil dari kritik eksternal dan internal tersebut menghasilkan fakta sejarah yang kemudian diinterpretasikan dengan menghubungkan antar data, sehingga diketahui fakta sejarah dalam sejarah perjuangan Indonesia dalam mempertahankan kemerdekaan tahun 1947-1949. Pada tahapan akhir dalam penelitian ini adalah historiografi yang dilakukan dengan jalan merangkai kalimat menjadi fakta-fakta sejarah menjadi kesatuan naratif yang menjelaskan 
sejarah perjuangan Indonesia dalam mempertahankan kemerdekaan tahun 1947-1949.

\section{Hasil dan Pembahasan Penelitian}

\section{Perjuangan Indonesia Dalam Mempertahankan Kemerdekaan Tahun 1947- 1949}

Kemerdekaan Indonesia yang sudah lama diidam-idamkan oleh seluruh masyarakat Indonesia, tidak dapat ditunda-tunda lagi setelah Jepang sebagai penjajah menyatakan diri menyerah kepada sekutu. Peristiwa kemerdekaan Indonesia ini disiarkan melalui siaran radio dan surat kabar agar seluruh rakyat Indonesia mengetahui jika bangsa Indonesia telah merdeka dan terbebas dari belenggu penjajahan asing. Sebenarnya semangat perjuangan untuk menjadi negara yang utuh dan merdeka sudah ada sejak zaman kerajaan di masa lalu (Rinardi, 2017). Peristiwa proklamasi kemerdekaan pada tanggal 17 Agustus 1945 telah menjadi sarana awal dalam perjuangan revolusi Indonesia untuk menjadi negara yang merdeka. Revolusi Indonesia pasca memerdekakan diri pada dasarnya disambut dengan semangat perjuangan dari banyak kalangan masyarakat dan tokoh-tokoh penting Indonesia. Semangat untuk menjadi bangsa yang mampu mengatur bangsanya sendiri muncul akibat sejarah bangsa Indonesia yang pernah menjadi negara besar di masa lalu. Saat setelah kemerdekaan Indonesia, semangat untuk mempertahankan kemerdekaan sebenarnya sangat bagus, namun beberapa pejuang masih ada yang memiliki egoisme yang tinggi (Zuhdi, 2014).

Peristiwa bersejarah proklamasi kemerdekaan Indonesia diterima masyarakat Indonesia berbeda-beda waktunya. Khususnya sebagian dari masyarakat di Sumatera Selatan, tepatnya di Palembang saat itu menerima berita proklamasi sekitar tanggal 18 Agustus 1945 yang masih bersifat sangat rahasia. Para tokoh kemerdekaan Indonesia di Palembang berupaya untuk mempersiapkan kemerdekaan Indonesia sebelum menyebarkannya ke seluruh wilayah wilayah Sumatera Selatan. Hal ini menandakan bahwa proklamasi merupakan hal yang sudah lama dicita-citakan oleh rakyat Indonesia sejak sekian lama. Seluruh rakyat Indonesia menyambut berita kemerdekaan Indonesia dengan penuh semangat dan suka cita (Yusuf Syafruddin, 2020).

Bangsa Indonesia berani berjuang untuk menjadi bangsa yang merdeka dilandasi semangat juang yang tinggi dan rasa cinta tanah air terhadap bangsanya. Selain bermodalkan semangat perjuangan yang hebat, bangsa Indonesia juga memiliki pengalaman berlatih militer dan pendidikan selama 
dijajah bangsa Jepang. Pada masa penjajahan Jepang. pihak Jepang memang telah memberikan banyak pengalaman kepada bangsa Indonesia melalui berbagai program pendidikan militer. Saat itu Jepang berkeinginan menggunakan masyarakat Indonesia sebagai pejuang Jepang di garis depan dalam melawan pasukan Sekutu. Ada sekitar lebih kurang dua juta pemudapemudi Indonesia yang tergabung dalam pendidikan militer seperti Seinendan, Keibodan, Heiho, Peta dan lain sebagainya dalam rangka perang asia timur raya. Adanya didikan militer ini, memberikan efek positif dengan timbulnya rasa percaya diri yang tinggi dalam mempertahankan harga diri yang seimbang dengan bangsa lainnya (Yasmis, 2007).

Untuk wilayah Sumatera Selatan pasca kekalahan Jepang atas pihak sekutu, sebenarnya pihak sekutu telah melarang keterlibatan Belanda dalam aksi melucuti senjata dan pasukan Jepang. Alasannya jelas karena pihak Indonesia yang telah membenci sikap Belanda selama berkuasa di Indonesia. Peristiwa penting di Palembang diketahui pada tanggal 13 Oktober 1945, pihak Sekutu dengan penumpang kapal perangnya telah memasuki Kota Palembang untuk melaksanakan kewajibannya dalam melucuti senjata pasukan Jepang. Pasukan Sekutu tersebut terdiri atas pasukan India, Gurkha, Pakistan, dan juga Inggris yang saat itu dibawah kepemimpinan Letnan Kolonel Carmichael. Atas informasi yang tidak melibatkan pihak Belanda tersebut, pendaratan tentara Sekutu tidak dicurigai oleh pihak Indonesia (Amin, 1992).

Beberapa daerah di Sumatera Selatan menjadi target untuk dikuasainya dengan berbagai agresi Belanda. Hal ini tidak mengherankan jika Belanda sangat tertarik untuk berkuasa atas wilayah Sumatera Selatan. Sebelum Jepang menguasai Indonesia, Belanda sudah lama berkuasa di Indonesia. Bahkan Belanda banyak membangun Kota-Kota penting di Palembang, Sumatera Selatan dengan sistem pemerintahan Keresidenan Palembang dengan Asisten Residen pemimpinnya. Wilayah di Sumatera Selatan yang banyak dilalui Sungai besar menjadi alasan terhadap kepentingan Belanda berkuasa kembali. Belanda percaya pihak-pihak yang masih setia untuk membela Belanda di Nusantara masih ada, termasuk di daerah Sumatera Selatan. Hal ini dikarenakan selama berkuasa di Sumatera Selatan, Belanda banyak mengangkat Pangeran sebagai pendampingnya dalam menjalankan kekuasaan. Para Pangeran ini dipilih dan diangkat oleh Belanda agar dapat menjadi penghubung antara Belanda dan masyarakat pribumi di masa lalu (Susilo, 2020).

Segala sesuatu yang dikhawatirkan bangsa Indonesia setelah kemerdekaan Indonesia pun akhirnya terjadi. Awalnya Sekutu datang ke Indonesia dengan tujuan untuk menjaga kondisi akibat perang. Selain itu 
tujuan Sekutu hanya melucuti senjata tentara Jepang dan mengirimnya kembali ke daerah asalnya (Batubara, 2019). Perjalanan bangsa Indonesia setelah kemerdekaan dilalui dengan masa perjuangan dengan revolusi fisik maupun dengan perundingan-perundingan.

Berdasarkan hasil rapat antar pemimpin Indonesia pada tanggal 17 Mei 1946 maka diketahui salah satu hasil dari perundingan tersebut diketahui bahwa Sumatera memiliki tugas Sub Komandemen, yang salah satunya Subkoss (Sub Komandemen Sumatera Selatan). Sub Komandemen Sumatera Selatan dibentuk dengan markasnya berpusat di Palembang. Untuk mendukung keberadaan Subkoss tersebut maka dibentuklah Divisi I Garuda dan Divisi II Garuda sebagai penopang Sub Komandemen Sumatera Selatan (Subkoss) (Susetyo, 2021).

Pejuangan bangsa Indonesia di masa 1945-1949 dapat dikatakan sebagai revolusi untuk perjuangan. Dalam membebaskan bangsa Indonesia dari masuknya kembali bangsa Belanda yang ingin menegakkan kekuasaannya ini sudah tidak diterima kembali oleh seluruh rakyat Indonesia. Bangsa Indonesia menginginkan menjadi negara yang merdeka dan berdaulat penuh atas negerinya sendiri. Bangsa Indonesia yang selama ini mengalami penjajahan yang menyebabkan rakyat semakin menderita, berusaha untuk melepaskan diri dari kolonialisme yang selama ini ada di negeri Indonesia. Di sisi lain keadaan Indonesia yang telah memerdekakan diri dengan telah banyaknya pemudapemudi yang berpendidikan tinggi menjadi pemicu semangat perjuangan menjaga kemerdekaan yang hakiki. Para golongan muda dan golongan tua berusaha berkolaborasi untuk menjadikan negara Indonesia sebagai negara yang merdeka. Selain itu, berusaha untuk mengatasi kemungkinankemungkinan yang terjadi saat Belanda berusaha untuk kembali berkuasa di Indonesia (Limah Hutri, 2018).

Perjalanan bangsa Indonesia yang penuh liku-liku perjuangan ini membuat masyarakat Indonesia menjadi lebih kuat dalam mengingat suatu peristiwa bersejarah di masa lalu. Banyak dokumen-dokumen sejarah yang menjadi pedoman peneliti sejarah untuk merekonstruksi peristiwa sejarah di masa lampau. Narasi-narasi sejarah yang dikembangkan dalam dunia pendidikan maupun bidang-bidang lainnya selalu disisipkan semangat patriotisme dan semangat pantang menyerah untuk mewujudkan cita-cita bangsa menjadi bangsa yang besar di masa depan (Pratama, 2018).

Perjuangan setelah kemerdekaan Indonesia tanggal 17 Agustus 1945, rakyat Indonesia berusaha untuk bersatu dalam menjaga keutuhan bangsa. Berbagai manifestasi politik agresi militer Belanda semakin dilancarkan tidak menyurutkan semangat persatuan dan kesatuan rakyat dalam menjaga 
Agus Susilo, Sarkowi

Sejarah Perjuangan Mempertahankan Kemerdekaan Indonesia

di Lubuklinggau Tahun 1947-1949

Republik Indonesia. Untuk mengatasi perlawanan rakyat Indonesia, Belanda banyak melakukan politik seperti membentuk Republik Indonesia Serikat atau RIS yang menjadi jembatan antara Indonesia dan Belanda dengan Ratu Belanda sebagai ketuanya. Indonesia dirasa Belanda belum layak menjadi negara yang berdiri sendiri dan merdeka. Belanda juga melakukan agresi militer Belanda 1 dan 2 yang menyebabkan bangsa Indonesia terdesak (Firza, 2017). Dalam mengatasi pertikaian antara pihak Indonesia dengan Belanda, maka diadakannya perundingan Linggarjati. Munculnya perjanjian Linggarjati, Roem Royen yang semuanya berusaha untuk memberikan keleluasaan kedua belah pihak mengatur kegiatannya. Berbagai gencatan senjata yang dilakukan oleh Belanda dan Indonesia, sering kali Belanda mengkhianati perjanjian. Hal ini terjadi seperti agresi militer Belanda II yang menyerang Kota Yogyakarta dan menawan pemimpin negara. Belanda berhasrat dengan menawan pemimpin negara, maka Republik Indonesia akan hilang. Namun rakyat Indonesia yang sudah cerdas dan pandai, memindahkan ibukota negara di Bukittinggi Sumatera Barat dibawah pimpinan Amir Syarifuddin.

\section{Peran Subkoss di Lubuklinggau Tahun 1947-1949 Sebagai Basis Pertahanan Indonesia di Sumatera Selatan}

Sumatera Selatan sangat luas wilayahnya yang banyak dialiri sungaisungai yang besar. Selain itu, aliran sungai yang besar, juga memberikan pengaruh pada perdagangan lokal di masa lalu. Sistem ekonomi di Sumatera Selatan sangat beranekaragam. Perkebunan dan pertanian dapat berkembang di wilayah ini. Selain itu, masyarakat Sumatera Selatan terbuka bagi para pendatang. Belanda di masa lalu banyak dibantu penduduk pribumi untuk memberitahu potensi-potensi daerah di Sumatera Selatan. Bangsa Belanda sangat membutuhkan Sumatera Selatan bukan hanya potensi wilayahnya yang luas, namun juga kekayaan alam di dalamnya. Belanda mengetahui potensi Sumatera Selatan yang berlimpah dari hasil alam dan kebutuhan industrinya seperti gas alam, minyak bumi, emas, dan lain sebagainya (Basundoro, 2012).

Serangan pasukan Belanda yang dilancarkan ke Indonesia pasca kekalahan Jepang atas Sekutu, telah membuat Belanda berkeinginan untuk menegakkan kekuasaannya di Indonesia. Wilayah Sumatera Selatan yang merupakan sumber kekayaan alam dengan menghasilkan berbagai macam tambang dan hasil bumi lainnya telah memicu Belanda untuk menegakkan kekuasaannya. Oleh karena serangan pasukan Belanda yang tidak pernah berhenti, maka pasukan Indonesia melakukan strategi dengan mundur ke beberapa wilayah di Sumatera Selatan, termasuk ke Lubuklinggau. Serangan 
pasukan Militer Belanda yang kedua pada tanggal 19 Desember 1948, telah membuat keadaan di Palembang saat itu tidak menentu. Staf Sub Komandemen Sumatera Selatan di pindahkan ke Lahat. Untuk menjaga keselamatan bersama dan mengatur strategi yang baik, markas Sub Komandemen Sumatera Selatan dipindahkan ke Lubuklinggau (Safitri, 2017).

Untuk saling menghubungkan antara pasukan Indonesia di Sumatera Selatan akibat Agresi Militer Belanda II ini membutuhkan waktu yang cukup lama. Hal ini dikarenakan saat itu sedang adanya perundingan terkait Belanda dan Indonesia yang dilakukan oleh Dewan Keamanan Perserikatan BangsaBangsa. Hasil dari perundingan ini menghasilkan suatu kesepakatan yang bernama Persetujuan Renville. Inti dari Persetujuan Renville ini adalah adanya garis pemisah antara pihak Belanda dan pihak Indonesia. Saat itu pihak Belanda hampir menguasai seluruh wilayah Nusantara dan pihak Indonesia hanya memiliki wilayah Jawa dan Sumatera sebagai wilayah kekuasaannya. Garis pemisah kekuasaan antara kedua belah pihak ini disebut dengan garis Demarkasi. Untuk wilayah Lubuklinggau pada saat itu garis Demarkasi berada beberapa kilometer dari kota Tebing Tinggi. Markas Garuda Merah berada di daerah Muara Beliti yang saat itu dipimpin oleh Bambang Utoyo (Simbolon, 1992).

Peperangan yang terjadi antara pihak Indonesia dan Belanda ini terjadi tidak hanya di wilayah Sumatera Selatan saja, namun juga terjadi di beberapa daerah di Indonesia. Faktor politik Belanda untuk menguasai sektor-sektor penting di Indonesia, menyebabkan keinginannya sangat kuat dapat menaklukan Indonesia dalam kurun waktu yang singkat. Segala upaya tersebut seolah tidak pernah berhasil. Masyarakat Indonesia yang zaman dahulu hidup sesuai lingkup daerahnya, setelah proklamasi kemerdekaan merasa antara satu bangsa di dalam negara Indonesia adalah saudara. Perjuangan tidak lagi sebatas kedaerahan, namun nasional. Selain itu keadaan Indonesia yang saat itu telah memiliki pejuang-pejuang handal dan pemimpin yang terkenal di dunia. Belanda sendiri tidak mudah menaklukan beberapa daerah di Indonesia. Para pejuang kemerdekaan Indonesia dalam melawan Belanda banyak mendapat dukungan dari bangsa-bangsa di dunia (Firza, 2016).

Peperangan yang terjadi di Kota Palembang Provinsi Sumatera Selatan sendiri sebenarnya adalah disebabkan oleh sabotase pasukan Belanda saat itu. Saat itu pasukan Belanda yang terdiri beberapa orang melakukan pelanggaran dengan memasuki wilayah Indonesia di Palembang. Hal ini sudah jelas melanggar peraturan yang telah disepakati bersama. Pihak Belanda telah melanggar batas wilayah atau yang lebih dikenal dengan garis Demarkasi. Pasukan Belanda yang saat itu sedang mabuk akibat perayaan sebuah pesta 
Agus Susilo, Sarkowi

Sejarah Perjuangan Mempertahankan Kemerdekaan Indonesia

di Lubuklinggau Tahun 1947-1949

memasuki wilayah Indonesia dengan dua Jeep yang mana melewati jalan Merdeka menuju Rumah sakit Charitas dan melepaskan tembakan yang ke segala arah. Hal ini menyebabkan kemarahan pasukan Indonesia dan membalas sabotase yang dilakukan pihak Belanda tersebut. Pertempuran ini akhirnya menimbulkan dampak yang besar bagi perjuangan bangsa Indonesia di Palembang (Susetyo, 2021).

Peristiwa-peristiwa yang merupakan sabotase Belanda ini akhirnya menyebabkan sebuah pertempuran yang hebat dengan beberapa hari lamanya. Perang yang besar di Palembang tersebut dikenal dengan sebutan Perang lima hari lima malam. Peperangan ini menyebabkan wilayah Palembang, khususnya dan umumnya Sumatera Selatan melakukan kewaspadaan terhadap aksi-aksi pemerintah Kolonial Belanda. Pertempuran besar di Palembang ini kemudian direspons oleh Panglima Sumatera Selatan Jenderal Mayor Suharjo Harjowardoyo dan Panglima Sub Komandemen Sumatera Selatan Kolonel Maludin Simbolon mengeluarkan "dog order" (perintah) melalui corong RRI di Palembang untuk tetap meningkatkan kewaspadaan. Hal ini banyak pendapat yang mengatakan bahwa memang disengaja kejadian-kejadian sabotase untuk mengundang amarah pasukan Indonesia di Palembang dan menimbulkan perang besar. Saat itu sebelum terjadinya perang lima hari lima malam, Panglima Sumatera Jenderal Suhardjo Harjowardoyo meninggalkan Kota Palembang dengan aman sebelum tragedy tersebut dilakukan Belanda. Jelas saat itu, sabotase Belanda dengan memancing kemarahan pasukan Indonesia dan menahan sang Jenderal (Amin, 1992).

Para pejuang kemerdekaan Indonesia di Sumatera Selatan dalam langkah mundur untuk mengatur strategi selanjutnya ini terus bergerak menuju Lubuklinggau. Sebelum mencapai Lubuklinggau, para pejuang ini melewati beberapa daerah seperti Prabumulih, Muara Enim, Lahat, Tebing Tinggi dan sampai pada tujuan Lubuklinggau. Pada saat itu, di Lubuklinggau telah berdiri Sub Komando Sumatera Selatan atau yang lebih dikenal dengan nama Subkoss Garuda Sriwijaya dengan pimpinannya Kolonel M. Simbolon. Sebagai pemimpin perjuangan kemerdekaan di Lubuklinggau ini, Kolonel M. Simbolon harus mampu mempertahankan Lubuklinggau agar tidak mudah dijangkau oleh Belanda yang saat itu sedang melakukan pengejaran. Untuk menghambat pasukan Belanda yang menuju Lubuklinggau, pihak pejuang melakukan blokade dengan membumihanguskan aset-aset penting, seperti membakar bangunan yang vital. Hal ini dilakukan agar gerakan-gerakan yang dilakukan oleh pihak militer Belanda dapat dihambat dan diserang balik (Amin, 1992). 
Beberapa tokoh perjuangan di Sumatera Selatan sangat bersemangat dalam menjaga keutuhan Indonesia saat itu. Dr. A.K. Gani yang merupakan pejuang kemerdekaan Indonesia di Sumatera Selatan, dalam usahanya menjaga kemerdekaan Indonesia sampai melakukan perjalanan jauh ke Muara Aman dengan menembus hutan dengan mobil Jeep dan melanjutkan perjalanan dengan Kuda. Tujuannya supaya perjuangan Indonesia di Sumatera Selatan dapat diketahui oleh seluruh rakyat Indonesia bahwa perjuangan para pejuang ini sangat luar biasa dan tidak diremehkan oleh pihak Belanda (Simbolon, 1992).

Agresi militer Belanda yang berkepanjangan tersebut akhirnya mendapatkan respon dengan adanya perjanjian Renville yang terjadi antara Indonesia dan Belanda pada tanggal 17 Januari 1948 diatas Kapal Amerika Serikat. Tentunya dengan adanya perjanjian Renville ini menjadikan peluang Indonesia untuk bertahan dari gempuran pasukan Belanda dapat lebih baik. Disisi lain, untuk membuat strategi yang lebih baik sangat penting di masa perundingan Renville ini. Dalam perundingan Renville ini ditandai dengan ditandatangani oleh masing-masing, yaitu:

a. Mr Amir Syarifuddin, yang saat itu sebagai Perdana Menteri Indonesia

b. Dr. H.J. Van Mook, sebagai Wakil dari pihak Belanda

Dalam perundingan tersebut dihasilkan keputusan sebagai berikut ini, yaitu:

1) Daerah yang telah menjadi kekuasaan Republik Indonesia, namun dikuasai oleh Tentara Belanda baik di Jawa maupun di Sumatera akan diadakan pemungutan suara rakyat dalam rangka menentukan status atau kedudukan wilayah-wilayah ini yang terdiri dari Negara Indonesia Serikat atau masuk dalam wilayah Republik Indonesia.

2) Tentara Nasional Indonesia (TNI) yang berada di daerah pegunungan namun masuk wilayah kekuasaan Belanda, harus berkenan untuk meninggalkan wilayah tersebut dan kembali ke wilayah yang masuk Republik Indonesia.

Pasca perundingan Renville yang diadakan oleh pihak Indonesia dan Belanda ini, wilayah Sumatera Selatan khususnya yang masih dikuasai oleh pihak Belanda, yaitu:

1) Palembang Bagian Utara, yaitu Babat Toman dan sekitarnya, Tebing Tinggi dan sekitarnya.

2) Palembang Bagian Tengah yang meliputi Kota Pagar Alam dan sekitarnya.

3) Palembang Bagian Selatan, ialah Kota Muara Dua dan Sekitarnya.

Sedangkan untuk wilayah Keresidenan Jambi, Bengkulu, dan daerah Keresidenan Lampung belum dikuasai oleh pihak Belanda. Belanda selama 
Agus Susilo, Sarkowi

Sejarah Perjuangan Mempertahankan Kemerdekaan Indonesia

di Lubuklinggau Tahun 1947-1949

agresi militer Belanda I dan II lebih berfokus pada wilayah Sumatera Selatan, khususnya di Palembang dan sekitarnya sebagai daerah tambang dan kekayaan alam lainnya sebagai pendukung kekuasaan Belanda (Usul, 1994).

\section{Simpulan}

Sumatera Selatan menjadi salah satu saksi perjuangan bangsa Indonesia dalam mempertahankan kemerdekaan Indonesia dari tahun 1947-1949. Belanda yang berusaha menguasai wilayah-wilayah di Indonesia termasuk Sumatera Selatan. Belanda sangat memahami bahwa wilayah di Sumatera Selatan memiliki kekayaan alam yang berlimbah yang dapat bermanfaat bagi kemajuan negara asalnya. Perang di Sumatera Selatan berawal dari sabotase pasukan Belanda terhadap para pejuang kemerdekaan Indonesia di wilayah Indonesia. Hal ini menimbulkan pertikaian yang menyebabkan saling tembak menembak. Setelah insiden tersebut, Belanda melakukan aksi perang terhadap pasukan TNI dan para laskar di Palembang. Perang di Palembang ini sangat rumit dan lama, sehingga dikenal dengan perang 5 hari 5 malam. Oleh karena bombardir pasukan Belanda dengan senjata yang lebih canggih, pasukan TNI dan para laskar menarik pasukan dari Kota Palembang untuk mengatur strategi perang selanjutnya.

Pasukan TNI dan laskar mundur sampai ke beberapa wilayah termasuk ke arah Lubuklinggau. Lubuklinggau sangat jauh dari Kota Palembang sebagai basis awal pasukan NKRI di Sumatera Selatan. Pasukan TNI dan laskar berusaha untuk menyusun rencana penyerangan pasukan Belanda yang telah menguasai beberapa wilayah di Sumatera Selatan. Kota Lubuklinggau menjadi salah satu saksi perjuangan pasukan TNI dan para laskar kemerdekaan. Di Kota Lubuklinggau sendiri saat itu didirikan Sub Komando Sumatera Selatan (Subkoss) Garuda Sriwijaya untuk mengatur perjuangan Indonesia dalam menghambat dan menahan pasukan Belanda yang terus masuk ke wilayah Lubuklinggau. Belanda memahami karena banyak pemimpin tertinggi di Sumatera Selatan yang berada di Lubuklinggau. Serangan Belanda terus masuk ke Lubuklinggau, namun dapat dihambat oleh para pejuang kemerdekaan. Sampai akhirnya Belanda mengakui kemerdekaan Indonesia setelah perjuangan yang tiada henti dari pejuang kemerdekaan Indonesia. Pada tahun 1949 Belanda mengakui Indonesia secara de facto dan de jure yang menjadikan negara Indonesia diakui oleh dunia. 


\section{Acknowledgment}

Dalam penelitian Sejarah ini, kami ucapkan puji syukur kepada Tuhan Yang Maha Esa yang telah melimpahkan berkah dan karunia-Nya, sehingga kami dapat menyelesaikan artikel penelitian dengan judul “Sejarah Perjuangan Indonesia: Kajian Historis Subkoss di Lubuklinggau Tahun 1947-1948”. Pada kesempatan ini kami ingin mengucapkan terima kasih kepada banyak pihak. Berkat bantuan dari berbagai pihak-pihak ini, maka akhirnya kami dapat menyelesaikan artikel penelitian ini. Oleh karena itu pada kesempatan ini kami mengucapkan terima kasih yang sebesar-besarnya kepada:

1. Bapak Dr. Rudi Erwandi, M.Pd selaku ketua STKIP PGRI Lubuklinggau yang telah memberikan motivasi dan dorongan kepada kami selaku dosen untuk meningkatkan produktivitas dan kualitas penelitian.

2. Bapak Viktor Pandra, M.Pd selaku kepala LP4MK beserta staf nya yang telah banyak memberikan dukungan, fasilitas, administrasi guna kelancaran penelitian.

3. Teman-teman dosen, khususnya dari Program Studi Pendidikan Sejarah yang telah memberikan dukungan dan semangat dalam penyelesaian penelitian ini.

4. Pihak-pihak lainnya yang tidak bisa kami sebutkan namanya satu persatu yang telah membantu dalam penyelesaian penelitian ini

\section{Daftar Rujukan}

Amin, H. B. (1992). Bunga Rampai: Perjuangan Sub Komandemen Sumatera Selatan (Subkoss) Garuda Sriwijaya. Musi Rawas: Perwakilan Yayasan Perjuangan

Subkoss Garuda Sriwijaya Kabupaten Daerah Tingkat II Musi Rawas.

Basundoro, P. (2012). Pengantar Sejarah Kota. Ombak.

Batubara, U. N. (2019). Perkembangan Pembelajaran Sejarah Pasca

Kemerdekaan-Reformasi. Jurnal Pendidikan Sejarah, 8(1), 14-34.

Cribb, Robert, dan A. K. (2012). Kamus Sejarah Indonesia. Komunitas Bambu.

Daliman. (2012). Metode Penelitian Sejarah. Ombak.

Fauziah Amatullah, D. (2020). Peranan Letnan I Nawawi Manaf Di Bengkulu

Pada Masa Revolusi Fisik Tahun 1945-1949. Agastya: Jurnal Sejarah Dan

Pembelajarannya, 10(1), 67-88.

Firza. (2016). Dari Perselisihan Menuju Kedamaian: Memahami Nilai-Nilai Resolusi

Konflik Melalui Pembelajaran Sejarah. Universitas Sanata Dharma.

Firza. (2017). The Important Role of Local Wisdom in Chacter Education.

Gottschalk, L. (2010). Mengerti Sejarah.(N. Notosusanto, Trans.). Yayasan Penerbit UI.

Kansil, C. S. T. \& J. (1984). Sejarah Perjuangan Pergerakan Kebangsaan Indonesia 
Agus Susilo, Sarkowi

Sejarah Perjuangan Mempertahankan Kemerdekaan Indonesia

di Lubuklinggau Tahun 1947-1949

(Pendidikan Sejarah Perjuangan Bangsa. Erlangga.

Karima, E. M., \& Firza, F. (2018). The Effect of Lectures and Question-Answer Methods of Teaching toStudents' Historical Thinking on History. ICSScE 2018.

Kartodirdjo, S. (2014). Pendekatan ilmu Sosial dalam Metodologi Sejarah. Gramedia Pustaka Utama.

Limah Hutri, D. (2018). Poster Dan Upaya Mempertahankan Kemerdekaan Indonesia di Yogyakarta Tahun 1945-1949. Journal of Indonesian History, $7(1), 35-44$.

https://journal.unnes.ac.id/sju/index.php/jih/article/view/25372

M. Loeb, E. (2013). Sumatra Sejarah dan Masyarakatnya. Ombak.

Pratama, R. A. (2018). Kecambuk Revolusi Kemerdekaan di Kuningan (19471950). Jurnal Candrasangkala, 4(2), 94-106.

https:/ / doi.org/http:/ / dx.doi.org/10.30870/candrasangkala.v4i2.4526

Rawas, P. M. (2002). Sejarah dan Peranan Subkoss Komandemen Sumatera Selatan (Subkoss) Dalam Perjuangan Rakyat Musi Rawas 1945-1950. Musi Rawas: Pemerintah Daerah Musi Rawas.

Ricklefs, M. C. (2007). Sejarah Indonesia Modern 1200-2004. III. Serambi.

Rinardi, H. (2017). Proklamasi 17 Agustus 1945: Revolusi Politik Bangsa Indonesia. Jurnal Sejarah Citra Lekha, 2(2), 143-150.

https://doi.org/https://doi.org/10.14710/jscl.v2i2.16170

Safitri. (2017). Kota, Sejarah Perekonomian Palembang: Masa Pemerintahan Kolonial Belanda, 1825-1942 M. UIN RADEN FATAH PALEMBANG.

Setiawan, J. \& A. (2018). KH. Ahmad Hanafiah: Pejuang Kemerdekaan Indonesia Asal Karesidenan Lampung. HISTORIA: Jurnal Program Studi Pendidikan Sejarah, 6(1), 129-138.

Simbolon, M. (1992). Bunga Rampai: Perjuangan Sub Komandemen Sumatera Selatan (Subkoss) Garuda Sriwijayax. Musi Rawas: Perwakilan Yayasan Perjuangan Subkoss Garuda Sriwijaya Kabupaten Daerah Tingkat II Musi Rawas.

Susetyo, B. \& R. (2021). Kota Lubuklinggau Dalam Kurun Waktu 1825-1948. Criksetra: Jurnal Pendidikan Sejarah, 10(1), 14-29. https://doi.org/10.36706/jc.v10i1.12902

Susilo, A. \& S. (2020). Sejarah Surulangun Sebagai Ibukota Onder Afdeling Rawas Tahun 1901-1942. Agastya: Jurnal Sejarah Dan Pembelajarannya, 10(1), 48-66. https://doi.org/http:// doi.org/10.25273/ajsp.v10i1.5109

Syam, S. (2010). Sejarah Museum Subkoss Garuda Sriwijaya di Lubuklinggau. Lubuklinggau: Yayasan Subkoss Garuda Sriwijaya Perwakilan Lubuklinggau.

Usul, A. M. (1994). Ringkasan Sejarah Perjuangan Rakyat Kabupaten Musi Rawas. Lubuklinggau: Yayasan Subkoss Garuda Sriwijaya Perwakilan Lubuklinggau.

Yasmis. (2007). Jepang dan Perjuangan Kemerdekaan Indonesia. Jurnal Sejarah LONTAR, 4(2), 24-32.

https://doi.org/https://doi.org/10.21009/LONTAR.0402 
DIAKRONIKA 21 (2) 2021

ISSN: 1411-1764 (Print) | 2620-9446 (Online)

Yusuf Syafruddin, D. (2020). Perjuangan Rakyat Musi Rawas Pada Masa Revolusi Fisik 1947-1949. Pendidikan Sejarah UNSRI.

Zuhdi, S. (2014). Sejarah Perjuangan Bangsa Sebagai Modalitas Memperkuat Pertahanan Negara. Jurnal Pertahanan, 4(1), 33-59. 